\title{
The Antiproliferative Activity of Colchicum umbrosum Plant Extract and Paclitaxel on C-4 I and Vero Cells
}

\author{
Ozlem Dagdeviren Ozsoylemez ${ }^{*}$ (D), Gul Ozcan² \\ 'Istanbul University, Institute of Graduate Studies in Science and Engineering, Department of Radiobiology, Istanbul, Turkey \\ ${ }^{2}$ Istanbul University, Faculty of Science, Department of Biology, Istanbul, Turkey
}

ORCID IDs of the authors: O.D.O. 0000-0001-9019-0757; G.O. 0000-0003-0682-5065.

Please cite this article as: Dagdeviren Ozsoylemez O, Ozcan G. The Antiproliferative Activity of Colchicum umbrosum Plant Extract and Paclitaxel on C-4 I and Vero Cells. Eur J Biol 2018; 77(2): 81-88.

\begin{abstract}
Objective: This study was conducted to determine the antiproliferative effects of paclitaxel (PAC) and Colchicum umbrosum plant extract on C-4 I and Vero cells. In addition, the apoptotic effects of plant extract on these cells were compared.

Materials and Methods: C-4 I and Vero cells were treated with PAC and corm extract of C. umbrosum for $24 \mathrm{~h}$. The antiproliferative effects of $0.01,0.1$, and $1 \mathrm{mg} / \mathrm{mL}$ of plant extract and $7.5,15$, and $30 \mathrm{nM}$ of PAC and the half maximal inhibitory concentration (IC50) values were determined by the MTT method. Morphological changes occurring in the C-4 I and Vero cells were observed under phase-contrast and fluorescence microscopes using DAPI staining.

Results: The IC50 values were found to be $0.01 \mathrm{mg} / \mathrm{mL}$ in C-4 I cells and $1 \mathrm{mg} / \mathrm{mL}$ in Vero cells for the plant extract and 15 $\mathrm{nM}$ in C-4 I and Vero cells for PAC. The apoptotic index (Al) values of the experimental groups of C-4 I and Vero cells were significantly increased compared to those of the control group $(p<0.01)$ after treatment with IC50 concentration of the plant extract. The Al values of the plant extract treatment in C-4 I cells were higher than those in Vero cells at 24 and $48 \mathrm{~h}$.

Conclusion: Treatment with the IC50 concentration of the plant extract induced apoptotic cell death in C-4 I cells. It can worth be considered as a novel promising candidate for the treatment of cancer.
\end{abstract}

Keywords: C-4 I, Vero, Colchicum umbrosum, paclitaxel, cancer

\section{INTRODUCTION}

Oncogenes, known as cancer genes, and tumor suppressor genes encode the components of the pathways that regulate the proliferative and social behavior of cells, and a molecular change in these can lead to the development of cancer (1). Natural products are considered a promising approach to cancer therapy with less toxic yet more potent effects. (2-4). Many chemotherapeutic agents used in clinics are produced from plant and analogs of the compound of it contains. Nowadays, the compounds obtained from plants in natural products (secondary metabolites) which have anticancer activity, cause apoptosis and regulate angiogenesis. Additionally, the metastasis potential of tumor cells have been identified (5-8). Some of the compounds and their derivatives such as paclitaxel, vinblastine, vincristine, etoposide, artemisinin, cannabinoid, resveratrol, camptothecin, derivatives of colchicine (Democolcine, $\mathrm{N}$-deacetylcolchicine, and trimethyl colchicinic acid) are secondary metabolites used as chemotherapeutics in the clinic $(3,6,8)$.

PAC, derived from the bark of Taxus brevifolia and having an antimitotic effect, has been used as a drug in some cancer therapy such as cancer of the uterus and breast cancer (9). The drug affects the normal functioning of the interphase as well as the microtubules in the mitosis. This effect of PAC has been shown to result from apoptosis of the resulting cell death (10). 
Colchicine is another secondary metabolite isolated from the species of Colchicum genus. Colchicine, an antimitotic agent that prevents the accumulation of microtubules, has antiproliferative effects due to its ability to inhibit cell division in the metaphase (11-13). Thus, the cells' death was actualized by using the apoptotic pathways (14).

Commonly, cancer cells are more susceptible to apoptosis themselves and the understanding of the molecular pathways that regulate apoptosis is beneficial in exploring the chemotherapeutic targets of cancer, which in turn will allow the discovery and development of new drugs. Recent studies have revealed that there are both natural and synthetic anticancer drugs mediating through apoptosis induction in order to prevent tumor expression, progression, and the emergence of cellular inflammatory responses other than necrosis (15-18). Apoptosis is a genetically controlled death which is found in both physiological and pathological conditions which are not needed or are dangerous to the organism. Given that apoptotic cells can be morphologically identified and counted by using phase contrast and fluorescence microscopy, they have used in the determination of the apoptotic index in tumor growths as a prognostic marker (19).

In this study, the antiproliferative effects of different doses of Colchicum umbrosum extract alone and PAC alone treated in C-4 I (cancer-acquired cell) and Vero cells (normal cell) were investigated using the MTT [3-(4, 5-dimethylthiazol-2-yl)-2, 5-diphenyltetrazolium bromide] method for 24 hours. Additionally, its IC50 values were determined. In this context, the aim was to determine the different antiproliferative effects of the chemotherapy drug and the plant extract on both the cancer and normal cells. Morphological changes in cells were shown with phase contrast and fluorescence microscopes with 4'-6-diamidino-2-phenylindole (DAPI). Furthermore, the apoptosis rate was determined using the apoptotic index parameter.

\section{MATERIALS AND METHODS}

Colchicum umbrosum Steven (corm, ISTE: 85333) plant was collected from Bolu-Abant in Turkey on 25.06.2008. The plant extract was percolated with pure methanol and lyophilized at Istanbul University Faculty of Pharmacy's Department of Pharmacognosy. Plant extract and PAC (Ebetaksel ${ }^{\circledR}$, Bristol Myers Squibb Co.) were prepared at different doses and applied on normal and cancer cells used in this study.

\section{Cell Lines}

Vero (normal cell line, green monkey kidney) and C-4 I (cancer cell line, human cervix carcinoma) cells were obtained from the ATCC (Vero: ATCC $^{\oplus}$ CCL-81; C-4 I: ATCC ${ }^{\oplus}$ CRL-1594) used in the experiments. 10\% Fetal Bovine Serum (FBS, Gibco Lab.) was added to the media used for these cells (Vero cells were MEM medium, C-4 I cells were in Waymouth MB medium) and $\mathrm{pH}$ was adjusted to7.2 with $4.4 \% \mathrm{NaHCO}_{3}$. Cells were incubated in sterile $25 \mathrm{~cm}^{2}$ flasks with regular passages twice a week at $37^{\circ} \mathrm{C}$ in a $5 \% \mathrm{CO}_{2}$ and $95 \%$ air mixture $(20,21)$.

\section{Passage Processes of Cells}

The Vero and C-4 I cells were passaged when they became monolayers in the culture containers where they grew. Cells were washed with Hank's Buffered Salt Solution and incubated with $2 \mathrm{ml}$ of $0.25 \%$ trypsin for 3 minutes to release them from the surface. The suspended cells were taken to the centrifuge tube and $4 \mathrm{ml}$ of the medium was added for the trypsin inactivation. Then, it was centrifuged at $500 \mathrm{xg}$ for 5 minutes. After this process, the supernatant part of the precipitated cells was removed $(20,21)$. The cells were palced in a 96 well plate for the antiproliferative experiment at 30,000 cells/well; and to determine the apoptotic index, the cells were seeded in 12 well plate at 200,000 cells per well. After the cultivation of the cells was carried out, incubation was carried out at $\mathrm{pH} 7.2$ for 24 hours at $37^{\circ} \mathrm{C}$ in an incubator containing $5 \% \mathrm{CO}_{2}$ and $95 \%$ air (21).

\section{Preparation of Concentration of Colchicum umbrosum Extract} The concentration of extracts prepared from the corm of C. umbrosum plant used in the experiments was determined with reference to the previous studies $(13,22)$. The dried extract was dissolved in a sterile, serum-free medium to prepare the stock solution. Then, 3 different concentrations of the plant extract $(0.01,0.1$ and $1 \mathrm{mg} / \mathrm{mL})$ were prepared by diluting the stock solution with a medium containing $10 \%$ FBS.

\section{Preparation of Doses of PAC}

The doses of PAC used were prepared taking into account the clinically applied doses. $30 \mathrm{mg} / 5 \mathrm{ml}$ of sterile stock solution was diluted with PAC (Ebetaksel ${ }^{\circledR}$, Bristol Myers Squibb Co.) serum-free medium, resulting in an intermediate stock of $7.5 \mu \mathrm{M}$. Three different doses (7.5 nM, $15 \mathrm{nM}$, and $30 \mathrm{nM}$ ) to be used in the experiments were prepared sterilely diluting them with the prepared intermediate-staged medium containing 10\% FBS and then applied to the cells (23).

\section{Treatment of Plant Extract and PAC in Cells}

3 different concentrations of the plant extracts alone and 3 different doses of PAC alone were applied to the cells for 24 hours. In the control group, the extract-free medium was used. At the end of these periods, the agents were removed and the analyses were carried out in accordance with the determined parameters.

\section{Determination of Cell Viability}

3 different concentrations of the plant extract and 3 different doses of PAC were treated in the cells and the IC50 values were determined for use in the experiments. At the end of the specified experiment period, the cells were removed from the 96-well plate and $40 \mu \mathrm{L}$ MTT $(5 \mathrm{mg} / \mathrm{mL})$ was added to the wells and incubated for 4 hours in a shaking incubator. To dissolve the formazan crystals which formed after 4 hours of incubation, $160 \mu \mathrm{L}$ of dimethyl sulfoxide was added to each well and left in the shaker incubator for 1 hour. Then, the absorbance at $570 \mathrm{~nm}$ wavelength reference of $690 \mathrm{~nm}$ wavelength was determined using ELISA spectrometry ( $\mu$ Quant, Bio-Tek Instruments INC.) In addition, the samples were photographed using phase-contrast microscopy to determine any morphological changes in the experimental groups (23). 


\section{Determination of Apoptosis}

At the end of the application times of $C$. umbrosum concentration on C-4 I and Vero cells, $1 \mathrm{~mL}$ was taken from the cell suspension in the experimental groups and collected in Eppendorf tubes and centrifuged at $1500 \mathrm{rpm}$ for 5 minutes at $4^{\circ} \mathrm{C}$. The supernatant was discharged and $200 \mu \mathrm{L}$ of the methanol: FTS (1:1) mixture was added. The supernatant was removed by centrifuge at 1500 rpm for 5 minutes. The pellet was resuspended in $200 \mu \mathrm{L}$ of pure methanol and stored at $+4^{\circ} \mathrm{C}$. For cleaning the slides, a mixture of ethanol: $\mathrm{HCl}(1: 1)$ was used. The slides were left in this mixture for 24 hours, washed in distilled water and stored at $+4^{\circ} \mathrm{C}$ for use. The cells, stored at $+4^{\circ} \mathrm{C}$ in Eppendorf tubes, were centrifuged again for 5 minutes at $1500 \mathrm{rpm}$, suspended in methanol and then dropped on cleaned slides and dried. The preparations prepared in this way were stained with DAPI for 20 minutes in a non-irradiated container at $37^{\circ} \mathrm{C}$ in a shaker incubator. After washing in PBS for 20 minutes, the coverslip was closed and examined under a fluorescence microscope. The Apoptotic index (Al) was determined by scoring both the normal nucleus and apoptotic nucleus in the preparations prepared according to the experimental groups. About 100 cells were counted in at least 30 sites for each experimental group, and the percentages of apoptotic cells to total cells for each area was calculated. The Al values were determined by averaging the percentages of the 30 areas for each experimental group (23).

\section{Statistical Analysis}

The arithmetic mean of the reproduction speed, the Al data determined by dose applied in all experimental groups, and the standard deviations were calculated. The results were examined to see if they showed any difference at a statistically significant level compared to the control group. For this purpose, the oneway ANOVA test was applied to all the values determined from the experimental groups. The significance of the groups compared to the control group was assessed using the Dunnett's test. A value of $p<0.05$ was considered statistically significant (GraphPad Prism Version 6.00, GraphPad Software, San Diego California USA).

\section{RESULTS}

In this study, the antiproliferative effects of PAC and $C$. umbrosum plant extract in Vero and C-4 I cells were evaluated using the MTT method.

3 different doses of PAC (7.5 nM, $15 \mathrm{nM}$ and $30 \mathrm{nM})$ and 3 different concentrations of plant extract $(1,0.1$ and $0.01 \mathrm{mg} / \mathrm{mL}$ ) were applied to the cells for 24 hours. In the statistical analysis, it was found that there was a significant difference between the control group and the experimental group where $1 \mathrm{mg} /$ $\mathrm{ml}$ concentration of plant extract was applied to the Vero cells $(p<0.05)$ (Figure 1). For C-4 I cells, it was determined that there was a significant difference between the experimental group and control group with 3 different concentrations of plant extract $(p<0.05)$ (Figure 2 ). In addition, a significant difference was found between the experimental groups and the control group

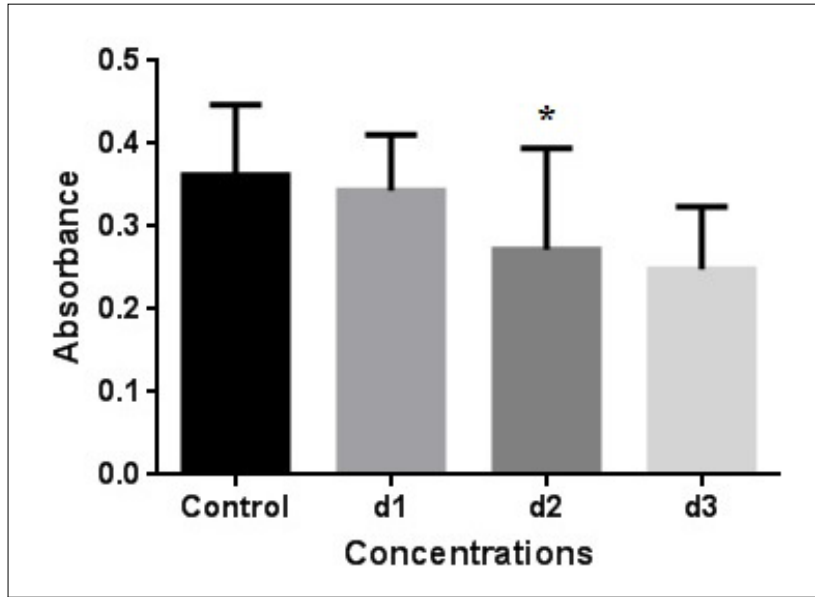

Figure 1. Measured absorbance values of Vero cells treated with different concentrations of $C$. umbrosum plant extract (d1: 0.01 $\mathrm{mg} / \mathrm{mL}$, d2: $0.1 \mathrm{mg} / \mathrm{mL}, \mathrm{d} 3: 1 \mathrm{mg} / \mathrm{mL}$ ) for $24 \mathrm{~h}$.

*Significantly different from control $(p<0.05)$.

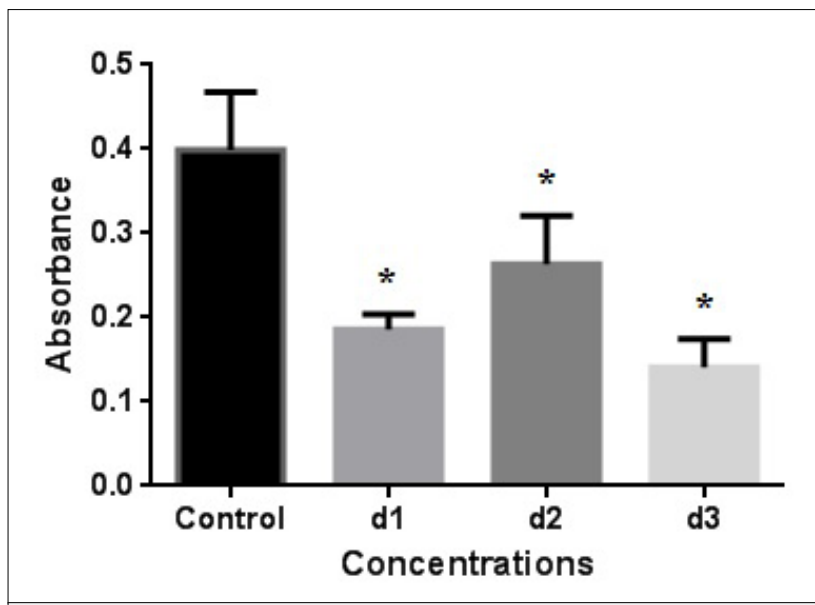

Figure 2. Measured absorbance values of $\mathrm{C}-4 \mathrm{I}$ cells treated with 3 different concentrations of $C$. umbrosum plant extract (d1: 0.01 $\mathrm{mg} / \mathrm{mL}, \mathrm{d} 2: 0.1 \mathrm{mg} / \mathrm{mL}, \mathrm{d} 3: 1 \mathrm{mg} / \mathrm{mL}$ ) for $24 \mathrm{~h}$.

*Significantly different from control $(p<0.05)$.

where PAC was applied at $15 \mathrm{nM}$ and $30 \mathrm{nM}$ doses to the Vero cells $(p<0.05)$ (Figure 3$)$. It was found that there was a significant difference between all the experimental groups and the control group in which 3 different doses of PAC were applied to the C-4 I cells $(p<0.05)$ (Figure 4).

The viability $\%$ values were determined as $94 \%$ for $0.01 \mathrm{mg} / \mathrm{mL}$, $75 \%$ for $0.1 \mathrm{mg} / \mathrm{mL}, 68 \%$ for $1 \mathrm{mg} / \mathrm{mL}$ concentration after the treatment of plant extract in Vero cells for 24 hours (Figure 5). The IC50 concentration was determined as $1 \mathrm{mg} / \mathrm{mL}$ in the Vero cells.

The viability $\%$ values were determined as $46 \%$ for $0.01 \mathrm{mg} / \mathrm{mL}$, $65 \%$ for $0.1 \mathrm{mg} / \mathrm{mL}, 35 \%$ for $1 \mathrm{mg} / \mathrm{mL}$ concentration after the treatment of plant extract in C-4 I cells for 24 hours (Figure 5). The IC50 concentration was found as $0.01 \mathrm{mg} / \mathrm{mL}$ in C-4 I cells. 
Eur J Biol 2018; 77(2): 81-88

Ozsoylemez and Ozcan. The Effect of Plant Extract and PAC in the Cells
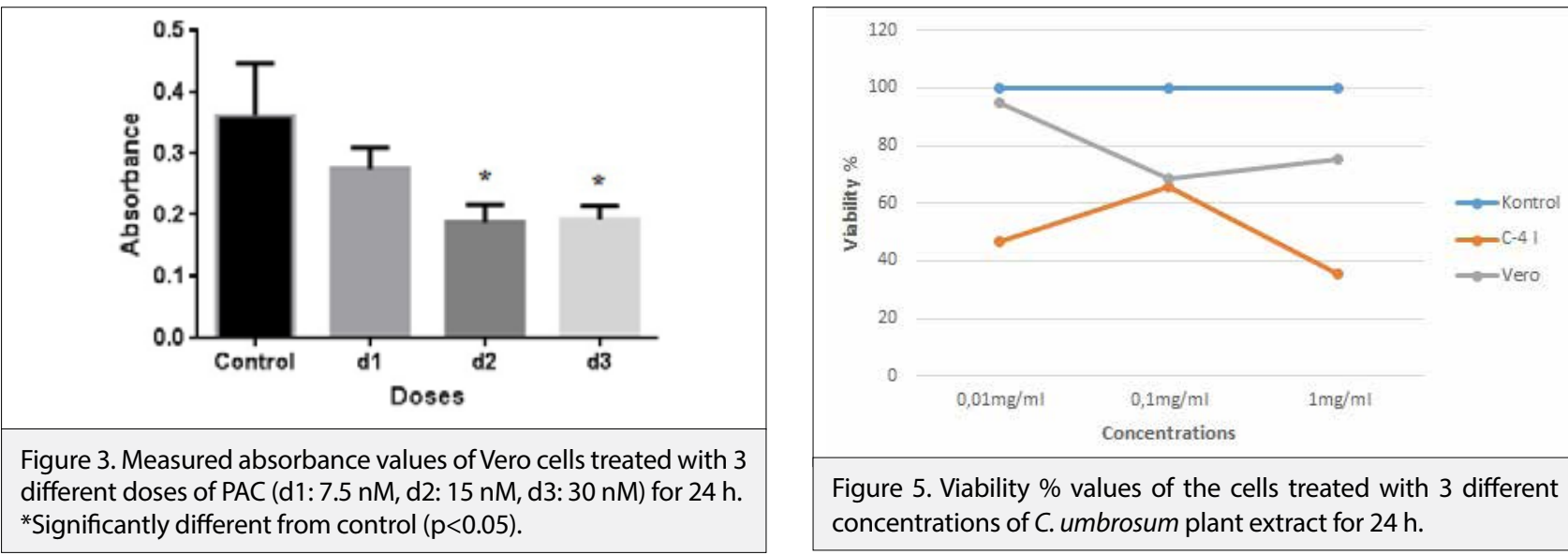

Figure 5 . Viability $\%$ values of the cells treated with 3 different concentrations of $C$. umbrosum plant extract for $24 \mathrm{~h}$.

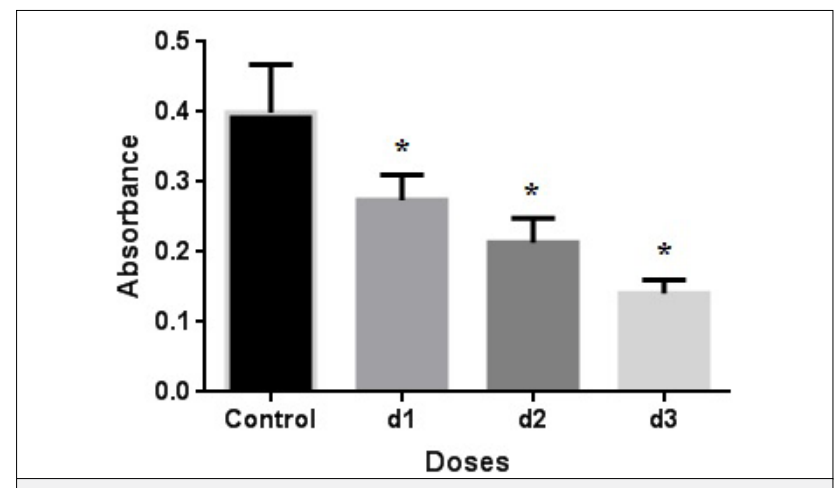

Figure 4. Measured absorbance values of $C-4$ I cells treated with 3 different doses of PAC (d1: $7.5 \mathrm{nM}, \mathrm{d} 2: 15 \mathrm{nM}, \mathrm{d} 3: 30 \mathrm{nM})$ for $24 \mathrm{~h}$. *Significantly different from control $(p<0.05)$.
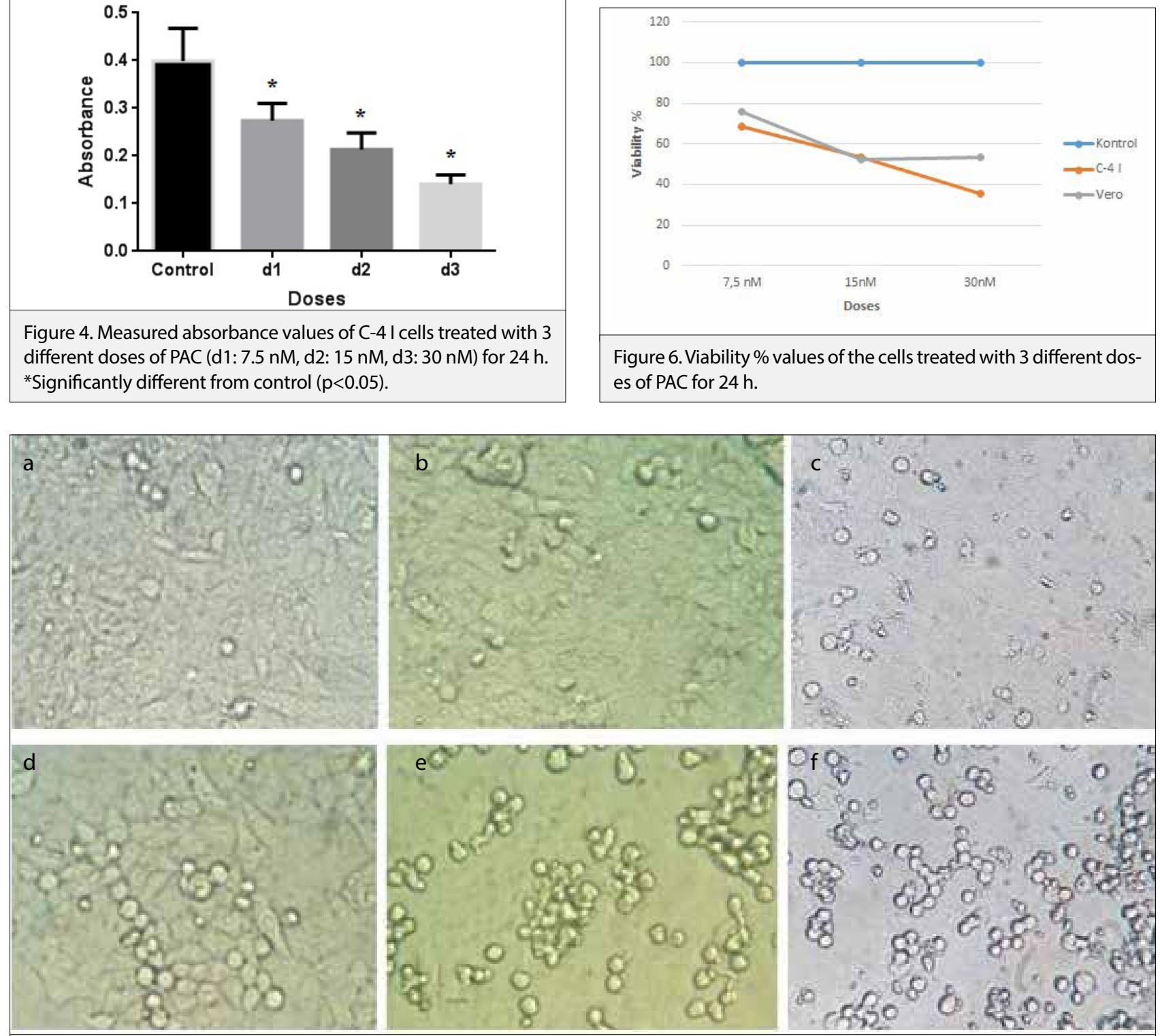

Figure 7. a-f. Phase-contrast microscopy image (x100) treated with IC50 values of plant extracts and PAC for $24 \mathrm{~h}$. a) Vero, Control; b) Vero, C. umbrosum; c) Vero, PAC; d) C-4 I, Control; e) C-4 I, C. umbrosum, f) C-4 I, PAC. 

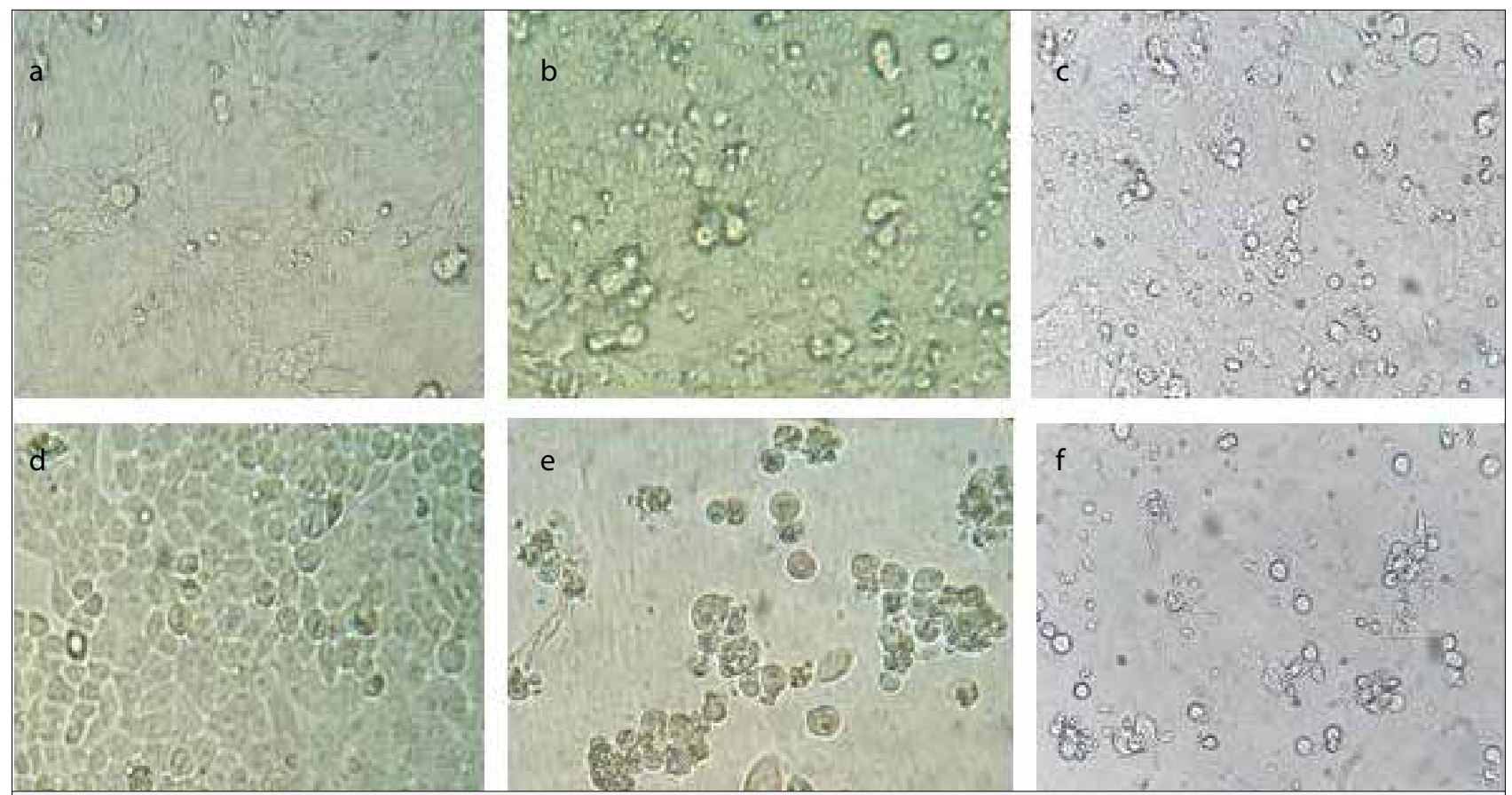

Figure 8. a-f. Phase-contrast microscope image (x100) treated with IC50 values of plant extracts and of PAC for $48 \mathrm{~h}$. a) Vero, Control; b) Vero, C. umbrosum; c) Vero, PAC; d) C-4 I, Control; e) C-4 I, C. umbrosum, f) C-4 I, PAC.
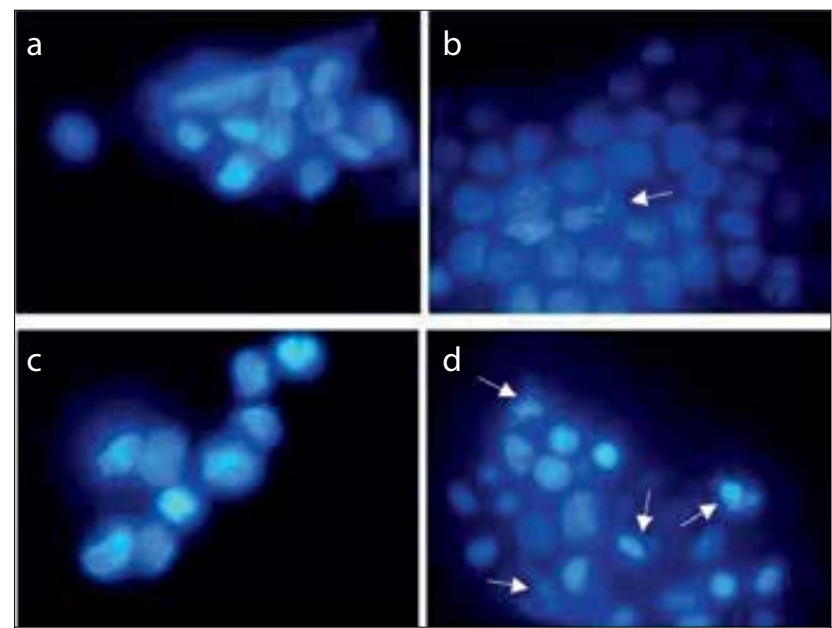

Figure 9. a-d. Fluorescence microscope image (x100) with DAPI of Vero and C-4 I cells for $24 \mathrm{~h}$. a) Vero, Control; b) Vero, experiment group; c) C-4 I, control; d) C-4 I, experiment group. ( $\rightarrow$ : apoptotic cells).

The viability \%values were determined as $76 \%$ for $7.5 \mathrm{nM}, 52 \%$ for $15 \mathrm{nM}, 53 \%$ for $30 \mathrm{nM}$ doses after the treatment of PAC in Vero cells for 24 hours (Figure 6). The IC50 dose was determined as $15 \mathrm{nM}$.

The viability $\%$ values were determined as $68 \%$ for $7.5 \mathrm{nM}, 53 \%$ for $15 \mathrm{nM}, 35 \%$ for $30 \mathrm{nM}$ doses after the treatment of PAC in C-4 I cells for 24 hours (Figure 6). The IC50 dose was determined as $15 \mathrm{nM}$.

Any morphological changes in the cells were shown using phase-contrast microscopy after the treatment of IC50 concentration of plant extracts and IC50 doses of PAC for 24 and 48 hours (Figures 7 and 8).
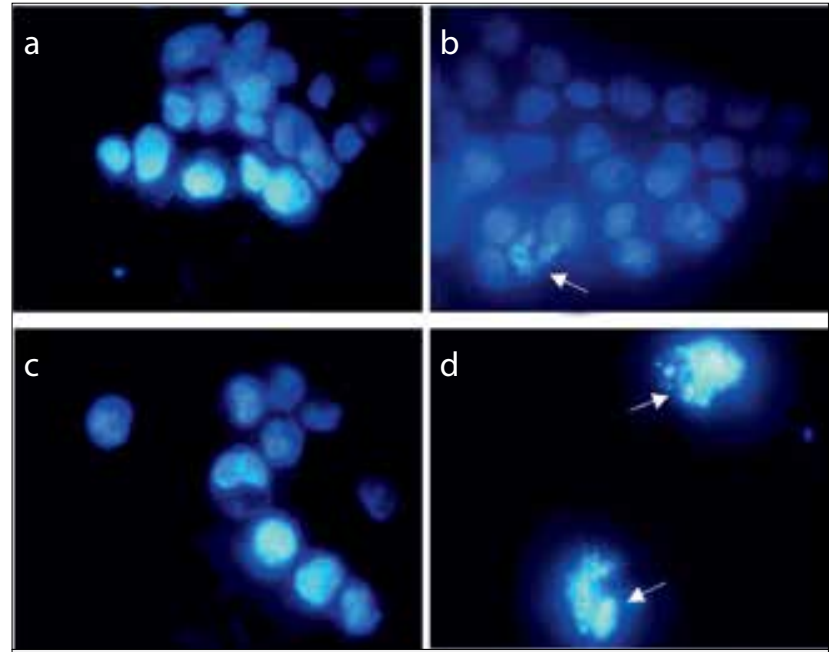

Figure 10. a-d. Fluorescence microscope image (x100) with DAPI of Vero and C-4 I cells for $48 \mathrm{~h}$. a) Vero, Control; b) Vero, experiment group; c) C-4 I, control; d) C-4 I, experiment group. ( $\rightarrow$ : apoptotic cells).

Nuclear condensation and apoptotic bodies formed during apoptosis induced by the plant extract were shown with a fluorescence microscope at $\times 100$ magnification (Figures 9 and 10).

The Al values were determined from the preparations prepared after administration of the IC50 concentration of the plant extract for 24 and 48 hours on the cells. This was done using fluorescence microscopy with DAPI, by counting at least 30 apoptotic and normal cells per 100 cells for each test group. 

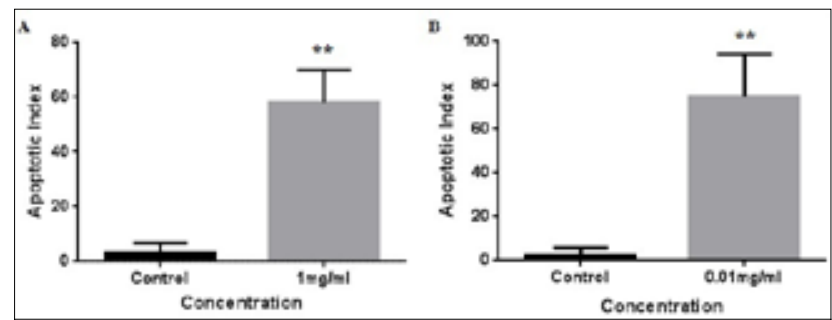

Figure 11. a, b. Apoptotic index values (a) Vero; b) C-4 I) of cells treated with IC50 concentration of the plant extract for $24 \mathrm{~h}$. ${ }^{* *}$ Significantly different from control $(p<0.01)$.
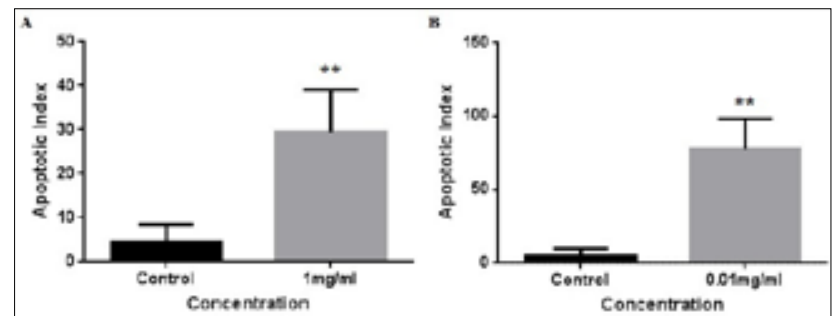

Figure 12. a, b. Apoptotic index values (a) Vero; b) C-4 I) of cells treated with IC50 concentration of the plant extract for $48 \mathrm{~h}$. **Significantly different from control $(p<0.01)$.

At the end of 24 hours, the Al values were found as 3\% for the control group and 58\% for the experiment group of Vero cell; $2 \%$ for the control group and $74 \%$ for the experiment group of C-4 I cell (Figure 11). It was determined that the difference between the experimental groups and the control groups was significant $(p<0.01)$.

At the end of 48 hours, $\mathrm{Al}$ values were found as $4 \%$ for the control group and $29 \%$ for the experiment group of Vero cell; $4 \%$ for the control group and $77 \%$ for the experimental group of C-4 I cell (Figure 12). The difference between the experimental groups and the control groups was significant $(p<0.01)$.

\section{DISCUSSION}

In this study, it has been shown that at $1,0.1$, and $0.01 \mathrm{mg} / \mathrm{mL}$ concentration of C. umbrosum plant extract applied on Vero and C-4 I cells during 24 hours caused a further decrease in the viability of cancer cells compared to normal cells. It has been determined that the IC50 concentration, which caused the death of approximately half of the cells of the plant extract at $1 \mathrm{mg} /$ $\mathrm{mL}$ in Vero cells and $0.01 \mathrm{mg} / \mathrm{mL}$ in C-4 I cells, between these three concentration, is the optimal concentration to be used at other stages of the study. According to this results, the plant extract more antiproliferative in C-4 I cells according to Vero cells.

MTT, known as one of the viability tests, is a rapid method used to determine the antiproliferative effect of agents on cells (23).

It was shown that PAC, commonly used in cancer chemotherapy, applied to Vero and C-4 I cells over 24 hours, causes a decrease in the viability of both normal cells and cancer cells at 7.5 $\mathrm{nM}, 15 \mathrm{nM}$ and $30 \mathrm{nM}$ doses. Of these three doses, the $15 \mathrm{nM}$ dose appears to be the optimal dose to be used in other stages of the study (called the IC50 dose), which causes the death of half of both cells.

In a study conducted, the antiproliferative effect of PAC on HeLa cells was determined. The optimal dose determination was found to be $\mathrm{nM}$ dose of the IC50 value of PAC and related viability values (23).

The Colchicum genus of the Liliaceae (Colchicaceace) family has been used for therapeutic purposes since ancient times. As a result of studies on Colchicum species, the substance named Colchicine was found in the structure. Colchicine shows anticancer properties because it can stop cell division in the metaphase. However, although it is known that colchicine, which is highly toxic at the desired doses for cancer treatment, has a potent antiproliferative effect, the therapeutic index is too low to be used therapeutically for this purpose. Derivatives of colchicine such as Demecolchine, $\mathrm{N}$-deacetylcolchine, and trimethyl colchicinic acid, are less toxic derivatives and have been shown to be more promising in cancer treatment (13).

In one study, the chemical constituents of the different parts of $C$. baytopiorum plant extract and their antiproliferative effects in $\mathrm{K} 562$ and HL60 cells were reported. In this study, colchicine, 2-demethylcolchicine, 3-demethylcolchicine, 3-demethyl-N-formyl-N-deacetylcolchicine, colchifoline, 2-demethylcolchifoline, demecolcine, 2-demethyldemecolcine and 2-demethyl- $\bigotimes$-lumicolchicine 12 were isolated from all the separated parts of C. baytopiorum. Additionally, the antiproliferative effects of different concentrations $(500,100,50,5,1$, and $0.1 \mu \mathrm{g} / \mathrm{mL})$ of all extracts prepared from the different parts of C. baytopiorum in K562 and HL60 cells were investigated. IC50 values were calculated and the results were compared with each other and with those for colchicine and demecolcine standards. According to this study, all extracts were more active than the demecolcine standard, and they also showed a similar activity to colchicine (13).

In a second report, the apoptotic effect of $0.1 \mathrm{mg} / \mathrm{ml}$ of C. baytopiorum plant extract on HeLa cells by using qRT-PCR was researched. According to this report, the regulatory genes' expression of apoptosis was significantly increased with the plant extract in the treatment group compared to the control group in HeLa cells (24). In other similar studies it was shown that colchicine may be more effective by interacting with other substances found in plant extracts (25-27).

Nowadays, anticancer therapies promote apoptosis using a variety of cellular signaling pathways. By elucidating the details of the apoptotic mechanism, new targets can be created in tumor treatment and it will be possible to increase the treatment efficiency. In this study, the apoptotic effect of the IC50 concentration of C. umbrosum plant extract in normal and cancer cells was investigated.

In attempts to improve the outcome of traditional cancer therapies, intensive investigations have been directed at various models of regulation of P53 and other key molecules involved 
in DNA damage network processes. In one model; the main role of the P53 pathway in determining cell destiny has been suggested either to activate the control points in the cell cycle or facilitate repair, thereby increasing survival or, inducing apoptotic cell death (28-30).

In a cell that enters the apoptotic death process, loss of volume, loss of contact with neighboring cells, chromatin condensation and orientation to the nucleus membrane, formation of recesses in the plasma membrane, and disruption of the apoptotic body of the cell are the main causes (31).

Previous studies regardig the $C$. umbrosum extract have determined that the plant extract has apoptotic effects on HeLa cells. In this report, it was shown that $0.1,0.5$, and $1 \mathrm{mg} / \mathrm{mL}$ concentrations of the plant extract had increased compared to the control group at 24 hours $(p<0.01)(22)$.

Goldstein et al. investigated apoptosis triggered in high and low dose UV irradiated HeLa cells by accelerated microscopy. It has been reported that the apoptotic process is of a certain duration and apoptosis is a process that progresses all or nothing, regardless of the amount of UV dose (32).

The determination of $\mathrm{Al}$ in malignant growth is accepted as a prognostic marker (19).

In this study, the formation of recesses and apoptotic bodies in the plasma membrane, which are morphologic changes in apoptosis induced by IC50 doses of C-4 I and Vero cells during 24 and 48 hour periods, were detected by fluorescence microscopy using DAPI application.

In this study, $0.01 \mathrm{mg} / \mathrm{mL}$ concentration of $C$. umbrosum plant extract caused an Al increase due to progression in C-4 I cells. It was determined that plant extract applied to Vero cells at a 1 $\mathrm{mg} / \mathrm{mL}$ concentration of plant showed a time-dependent decrease in the cells. In this context, it has been shown that the plant extract used induces more cell death in cancer cells than in normal cells.

\section{CONCLUSION}

It has been shown that $C$. umbrosum plant extract applied on normal and cancer cells cause a decrease in mitochondrial dehydrogenase enzyme activity from cell kinetics parameters of cancer cells, resulting in an increase in Al. In normal cells, the cell death rate is less than in cancer cells and Al decreases with time. It was found that PAC caused more cell death in normal cells compared to the plant extract application. The strategy applied in cancer treatment is to reduce chemotherapy drugs in cancer cells while increasing survival in normal cells. In this context, it is thought that the use of plant extract in the treatment of cancer according to PAC, which is the chemotherapy drug used in treatment, is more promising.

Peer-review: Externally peer-reviewed.
Author Contributions: Concept - O.D.O., G.O.; Design - O.D.O., G.O.; Supervision - O.D.O., G.O.; Resource - O.D.O.; Materials - O.D.O.; Data Collection and/ or Processing - O.D.O., G.O.; Analysis and/or Interpretation - O.D.O.; Literature Search - O.D.O., G.O.; Writing - O.D.O., G.O.; Critical Reviews - O.D.O., G.O.

Acknowledgements: Authors of this manuscript are grateful to Prof. Dr. Nurhayat Sutlupinar and Dr. Sevda Pirildar for providing the facilities to prepair of plant extraction.

Conflict of Interest: The authors have no conflict of interest to declare.

Financial Disclosure: This work was supported by the Research Fund of Istanbul University.

\section{REFERENCES}

1. Johnstone RW, Ruefli AA, Lowe SW. Apoptosis: a link between cancer genetics and chemotherapy. Cell 2002; 108(2): 153-64.

2. Catalano E, Maestri P, Cochis A, Azzimonti B, Varoni EM, Fraschini F, et al. Cytotoxic activity of a plant extract on cancer cells. Ital J Anat Embryol 2013; 118(2): 50.

3. Demirgan R, Karagoz A, Pekmez M, Onay-Ucar E, Artun FT, Gurer C, et al. In vitro anticancer activity and cytotoxicity of some papaver alkaloids on cancer and normal cell lines. Afr J Tradit Complement Altern Med 2016; 13(3): 22-6.

4. Peña-Morán OA, Villarreal ML, Álvarez-Berber L, Meneses-Acosta A, Rodríguez-López V. Cytotoxicity, post-treatment recovery, and selectivity analysis of naturally occurring podophyllotoxins from Bursera fagaroides var. fagaroides on breast cancer cell lines. Molecules 2016; 21(8): pii: E1013.

5. Gupta A, Naraniwal M, Kothari V. Modern extraction methods for preparation of bioactive plant extracts. IJANS 2012; 1(1): 8-26.

6. Korkina $L$ and Kostyuk V. Biotechnologically produced secondary plant metabolites for cancer treatment and prevention. Curr Pharm Biotechno 2012; 13(1): 265-75.

7. Ramasamy S, Wahab N.A, Abidin N.Z, Manickam S, Zakaria Z. Growth Inhibition of human gynecologic and colon cancer cells by Phyllanthus watsonii through apoptosis induction. PLoS One 2012; 7(4): e34793.

8. Kma L. Roles of plant extracts and constituents in cervical cancer therapy. Asian Pac J Cancer Prev 2013; 14(6): 3429-36.

9. Sgadari C, Toschi E, Palladino C, Barillari G, Carlei D, Cereseto A, et al. Mechanism of paclitaxel activity in Kaposi's Sarcoma. J Immunol 2000; 165(1): 509-17.

10. Jordan MA, Wendell K, Gardiner S, Derry WB, Copp H, Wilson L. Mitotic block induced in HeLa cells by low concentrations of paclitaxel (Taxol) results in abnormal mitotic exit and apoptotic cell death. Cancer Res 1996; 56(4): 816-25.

11. Combeau C, Provost J, Lancelin F, Tournoux Y, Prod'homme F, Herman F, et al. RPR112378 and RPR115781: two representatives of a new family of microtubule assembly inhibitors. Mol Pharmacol 2000; 57(3): 553-63.

12. Dumontet $\mathrm{C}$, Sikic BI. Mechanisms of action of and resistance to antitubulin agents: microtubule dynamics, drug transport, and cell death. J Clin Oncol 1999; 17(3): 1061-70.

13. Pirildar S, Sutlupinar N, Atasever B, Erdem Kuruca S, Papouskova B, Śimánek V, Chemical constituents of the different parts of Colchicum baytopiorum and their cytotoxic activities on K562 and HL60 cell lines. Pharm Biol 2010; 48(1): 32-9. 
14. Jordan MA, Wilson L. Microtubules as a target for anticancer drugs. Nat Rev 2004; 4(4): 253-65.

15. Piccolella M, Crippaa V, Messia E, Tetel MJ, Poletti A. Modulators of estrogen receptor inhibit proliferation and migration of prostate cancer cells. Pharmacol Res 2014; 79: 13-20.

16. Wu CT, Lai JN, Tsai YT. The prescription pattern of Chinese herbal products that contain Dang-Qui and risk of endometrial cancer among Tamoxifen-treated female breast cancer survivors in Taiwan: A population-based study. PLoS One 2014, 9(12): e113887.

17. Binkhorst L, Mathijssen R.H, Jager A, van Gelder T. Individualization of tamoxifen therapy: Much more than just CYP2D6 genotyping. Cancer Treat Rev 2015; 41(3): 289-99.

18. Bisi A, Gobbi S, Merolle L, Farruggia G, Belluti F, Rampa A, Molnar $J$, et al. Design, synthesis and biological profile of new inhibitors of multidrug resistance associated proteins carrying a polycyclic scaffold. Eur J Med Chem 2015; 92: 471-80.

19. Chauhan R, Verma N, Sharma SP, Bhargava R, Singh P. Role of apoptotic index, mitotic index and MIB-1 antibody expression as biomarkers in preneoplastic and neoplastic lesions of uterine cervix. Int J Res Med Sci 2016; 4(6): 2093-100.

20. Artun FT, Karagoz A, Ozcan G, Melikoglu G, Anil S, Kultur S, et al. In vitro anticancer and cytotoxic activities of some plant extracts on HeLa and Vero cell lines. Proceedings 2017; 1: 1019.

21. Ozcan G, Dagdeviren Ozsoylemez O, Akman G, Khalilia W, Tezel B.Y, Karagoz A, Melikoglu G, Anil S, Kultur S, Sutlupinar N. Screening for antitumor activity of various plant extracts on HeLa and C 4-I cell lines. J BUON 2016; 21(6): 1552-60.

22. Dağdeviren Ö. Acı Çiğdem (Colchicum umbrosum S. ve Colchicum baytopiorum C.D.) ekstrelerinin Hela hücreleri üzerine anti-tümöral etkilerinin araştırılması. iÜ Fen Bilimleri Enstitüsü, Yüksek Lisans Tezi. 2010.
23. Serbes U, Ozsoylemez OD, Ozcan G. Evaluation of paclitaxel effects in the pattern of expression of survival and apoptotic genes regulators in HeLa cells. Curr Pharm Biotechnol 2016; 17(12): 1058-67.

24. Ozsoylemez OD, Ozturk M, Sutlupinar N, Kayacan S, Tuncdemir $M$, Ozan $G$. The effects of Colchicum baytopiorum on regulatory genes of apoptotic and autophagic cell death in HeLa cells. Curr Pharm Biotechnol 2016; 17(15): 1369-76.

25. Solowey E, Lichtenstein M, Sallon S, Paavilainen H, Solowey E, Lorberboum-Galski $\mathrm{H}$. Evaluating medicinal plants for anticancer activity. ScientificWorldJournal 2014; 2014: 721402.

26. Delebinski C, Georgi S, Kleinsimon S, Twardziok M, Kopp B, Melzig $M F$, et al. Analysis of proliferation and apoptotic induction by 20 steroid glycosides in 143B osteosarcoma cells in vitro. Cell Prolif 2015; 48(5): 600-10.

27. Radogna F, Dicato M, Diederich M. Cancer-type-specific crosstalk between autophagy, necroptosis and apoptosis as a pharmacological target. Biochem Pharmacol 2015; 94(1): 1-11.

28. Mirzayans R, Andrais B, Scott A, Murray D. New insights into p53 signaling and cancer cell response to DNA damage: implications for cancer therapy. Biomed Res Int 2012; 2012: 170325.

29. Ganapathy S, Xiao S, Yang M, Qi M, Choi DE, Ha CS, et al. A low-dose arsenic-induced p53 protein-mediated metabolic mechanism of radiotherapy protection. J Biol Chem 2014; 289(8): 5340-7.

30. Aubrey BJ, Kelly GL, Janic A, Herold MJ, Strasser A. How does p53 induce apoptosis and how does this relate to p53-mediated tumour supression? Cell Death Differ 2018; 25(1): 104-13.

31. Gewies A. Introduction to Apoptosis. ApoReview 2003; 1-26.

32. Goldstein JC, Kluck RM, Green DR. A single cell analysis of apoptosis: ordering the apoptotic phenotype. Ann N Y Acad Sci 2000; 926(1): 132-41. 